Original Research Paper

\title{
Effects of Bradyrhizobium japonicum on Some Chemical Properties of Ferralsols under Soybean (Glycine max (L.) Merr.) Cultivation
}

\author{
${ }^{1}$ Ben Tshibuyi Kasu-Bandi, ${ }^{3}$ Laurent Kidinda Kidinda, ${ }^{2}$ Germain Nyembo Kasendue, \\ ${ }^{3}$ John Banza Mukalay, ${ }^{1}$ Meschac Ilunga Tshibingu, ${ }^{3}$ Mick Assani Bin Lukangila, \\ ${ }^{3,4}$ Louis Baboy Longanza, ${ }^{3}$ Kasongo Lenge Emery and ${ }^{3,5}$ Antoine Kanyenga Lubobo

\begin{abstract}
${ }^{I}$ National Institute for Agricultural Research and Study (INERA), Kipopo Station, P. O Box 224; Lubumbashi, DR Congo
${ }^{2}$ Agricultural Economics, Faculty of Agricultural Sciences, University of Kinshasa, P.O Box 117, Kinshasa XI, DR Congo

${ }^{3}$ Faculty of Agricultural Sciences, Université de Lubumbashi, Lubumbashi, DR Congo; P.O Box 1825, DR Congo

${ }^{4}$ Scientic Collaborator at Université Libre de Bruxelles, Inter-Faculty School of Bioengineers, Landscape Ecology Service and Crop Production Systems, P.O Box 1050 Brussels, Belgium

${ }^{5}$ International Center for Tropical Agriculture, Harvest Plus, DR Congo
\end{abstract}

\section{Article history}

Received: 17-08-2019

Revised: 09-10-2019

Accepted: 16-10-2019

Corresponding Author: Ben Tshibuyi Kasu-Bandi, National Institute for Agricultural Research and Study (INERA), Kipopo Station, P.O Box 224; Lubumbashi, DR Congo Email: bentshibuyi@yahoo.fr

\begin{abstract}
This study was conducted on acidic soils in two different agroecological zones in order to evaluate the influence of Bradyrhizobium japonicum on soil chemical properties in the Upper-Katanga (DR Congo). A split plot design with three replicates was installed in two sites. The main plots included three strains of Bradyrhizobium japonicum plus the untreated control and four soybean varieties in subplots. Seed inoculation was performed in the shade and sown on the same day. The results showed that Bradyrhizobium strains did not influence soil $\mathrm{pH}$, Nitrogen, $\mathrm{C}$ : $\mathrm{N}$ ratio and organic matter neither at flowering nor at harvest. However, total and available phosphorus (P) were influenced by the different treatments at harvest in Kanyameshi site. The strain S1 induced the highest average of total and available $\mathrm{P}$ whereas, the strain $\mathrm{S} 2$ had the lowest value of total $\mathrm{P}$, and $\mathrm{S} 3$ induced the lowest content in available P. By comparing the timing of soil sampling at flowering and harvesting, the Student test revealed significant differences in $\mathrm{pH}$, total nitrogen, $\mathrm{C}$ : $\mathrm{N}$ ratio, organic matter and available $\mathrm{P}$ indicating that soil chemical properties was improved at harvest and are only partially influenced by applied Bradyrhizobium strains.
\end{abstract}

Keywords: Soybean, Inoculum, Soil Fertility, Haut-Katanga

\section{Introduction}

In sub-Saharan Africa, soils fertility is fundamentally low and exported nutrients are not adequately replaced (FAO, 2003; Mulaji, 2011) and nutrient depletion is a major aspect of soil degradation (Useni et al., 2014; Mulaji, 2011). This situation leads in a drastic deficiency of mineral nutrients necessary for plant growth, which would be the basis of low crop yields (Houngnandan et al., 2001; Javaheri and Baudoin, 2001). However, the sustainable management of soil fertility in humid tropical countries is still topical, especially since the majority of agricultural production in tropical soils is still based on the traditional farming systems.

Notably, agricultural production, which has leapt forward in recent decades, will have to grow even further in the future, as the world population has also increased (FAO, 2005). To meet future food needs, it will clearly be necessary to continue to rely on inorganic nitrogen fertilizers while their consequences for the environment are well established (Kasongo and Banza, 2015).

Obviously, legumes play a significant role in soil improvement by their symbiotic association with soil bacteria of the rhizobium group and allow fixing up to 300 $\mathrm{kg} \mathrm{N} \mathrm{ha}^{-1}$ year $^{-1}$ under good conditions (Smith and Hume, 1987). Therefore, the use of legumes in rotation and crop associations is of great important (Manyong et al., 1996; Carsky et al., 1997; Mako et al., 213; Useni et al., 2013), since it may reduce the costs and limit the damage caused by mineral fertilizer input (Kasongo and Banza, 2015). In this family of plants, soybean (Glycine max (L.) Merr.) is an important grain legume crop in the world in terms of total production and international trade (Kasongo and Banza, 2015; Baboy et al., 2015). In the Democratic Republic of Congo, during the years 2003-2013, soybean yield varied from 4750 to $5476.19 \mathrm{Kg}$ per hectare (www.fao.org). These yields are lower than that obtained in several countries including Kenya (3.76 t ha ${ }^{-1}$, Verde et al. (2013), Serbia - 
$4.35 \mathrm{t} \mathrm{ha}^{-1}$ - (Mrkovački et al., 2008) and Tanzania where Phosphorus addition and inoculation allowed to reach $10.837 \mathrm{t} \mathrm{ha}^{-1}$ (Tairo and Ndakidemi, 2013). A study conducted by Shahid et al. (2009) reported that soybean seed production could increase by $70-75 \%$ when soybeans are inoculated with appropriate bacterial rhizobium. As rhizobium can meet plant need in $\mathrm{N}$, the use of additional inoculum could not only increase plant productivity but also $\mathrm{N}$ balance in the soil. Obviously, $\mathrm{N}$ is essential to the development of microorganisms in the rhizosphere, leading to the increased decomposition of soil organic matter and enhanced $\mathrm{P}$ availability because of mycorrhiza activities. However, the extent to which Bradyrhizobium strains could improve the fertility of ferralsols is not clear.

This study aims to study the effects of Bradyrhizobium Japonicum on some soil chemical properties of ferralsols for evaluating the efficiency of biological fertilization.

\section{Materials and Methods}

\section{Description of the Study Area}

The experiments were conducted during the 20152016 cropping season in two sites. The first experiment was conducted at the experimental field of the Faculty of Agricultural Sciences of the University of Lubumbashi University (UNILU) and located at $1100 \mathrm{~m}$ altitude, $11^{\circ} 60869^{\prime} \mathrm{S}$ and $027^{\circ} 47692^{\prime} \mathrm{E}$. The second experiment was conducted in the territory of Kipushi, precisely in Kanyameshi located at $11^{\circ} 45^{\prime} 25^{\prime \prime} \mathrm{S}$ and $27^{\circ} 16^{\prime} 59^{\prime} \mathrm{E}$ and $1320 \mathrm{~m}$ altitude. The annual rainfall in these agroecological zones is around $1270 \mathrm{~mm}$ with a rainy season of 118 days, while the average annual temperature is around $20^{\circ} \mathrm{C}$ with great inter-annual stability. The rainy season runs from November to March, the dry season from May to September, while April and October are the transition months (Kasongo et al., 2013). The area is characterized by ferralitic soil type with a $\mathrm{pH}$-water oscillating around 5.2 (Kwey et al., 2015).

\section{Materials}

Four soybean varieties and three strains of Bradyrhizobium were used as biological material. Among these four soybean varieties, two (TGX 1740-7F and 1880-3E) were obtained at the National Institute for Agricultural Research and Study (INERA), Kipopo Station. The other two varieties were obtained in Zambia (MUKANGA from ZAMSEED and PAN 1867 from PANNAR). Three commercial inoculum strains of the genus Bradyrhizobium were used. Bradyrhizobium sp strain of pasty formulation, Sojapak ® 50 liquid formulation strain and GraphExTM powder formulation strain. The strain Bradyrhizobium sp was provided by the National Service of Fertilizer and Input (SENAFIC) and the other two strains (Sojapak @ 50 and GraphExTM) were obtained on the local market.

\section{Conduct of the Experiment}

Soil samples from the topsoil $(0-20 \mathrm{~cm})$ were collected before the setup of experiment, at flowering and at harvesting. The experiment was installed following a Split Plot device with three replicates. Three strains of Bradyrhizobium plus the untreated control and four soybean varieties where used. The combination of different strains and varieties resulted in 16 treatments. Planting was done at $0.40 \times 0.20 \mathrm{~m}$ spacing at the rate of 2 seeds per pocket, i.e., a density of 250000 plants per hectare. The planting took place respectively in January 9 and 10, 2016 in Lubumbashi and Kipushi. Inoculation of soybean seeds was done at planting for concerned treatments. For symbiotic inoculation, a single procedure was used for all formulations to ensure that all seeds receive a thin layer of the inoculant. All inoculations were done in the shade just before planting in order to maintain the viability of the bacterial cells.

\section{Laboratory Analysis and Statistics}

All chemical analyses were performed on air-dried soil fractions $(<2 \mathrm{~mm})$. Soil $\mathrm{pH}$ was measured potentiometrically in a 1:2.5 (W/V) suspension of $\mathrm{H}_{2} \mathrm{O}$. Organic carbon content ( $\mathrm{C}_{\text {org }}$, Walkley and Black) was determined as described by Van Ranst et al. (1999). The method is based on the oxidation of the organic matter by potassium dichromate $\left(\mathrm{K}_{2} \mathrm{Cr}_{2} \mathrm{O}_{7}\right)$ in a strongly acid medium $\left(\mathrm{H}_{2} \mathrm{SO}_{4}\right)$. Total nitrogen and available phosphorus were determined by Kjeldahl and Bray II methods respectively, as described by Van Ranst et al. (1999).

One-way Anova was used to evaluate the effects of Bradyrhizobium strains on soil chemistry, with a posthoc TUKEY test in case of differences between treatments. The Student test was applied to compare the sampling time (flowering and harvesting). All analyses were performed using Minitab 17 software considering $\mathrm{P}$ $<0.05$ as the level of significance

\section{Results}

\section{Effect of Rhizobial Strains on Soil pH at Flowering and Postharvest}

Figure 1 illustrates the variation of soil $\mathrm{pH}$ at flowering and harvest based on rhizobia strains in the Kanyameshi and Kasapa sites. As a result, the different strains of rhizobium did not influence $\mathrm{pH}$ at flowering $(\mathrm{p}$ $=0.753)$ and harvest $(\mathrm{p}=0.609)$. However, the $\mathrm{pH}$ varied in this site between 6.07 (S0) and $6.3(\mathrm{~S} 2)$ at flowering, 6.6 (S3) and 6.7 (S0, S1, S2) at harvest. The same trend is observed in the Kasapa site where the different strains of Bradyrhizobium did not influence $\mathrm{pH}$ neither at flowering $(\mathrm{p}=0.339)$ nor at harvest $(\mathrm{p}=0.57)$. However, the results showed highly significant differences after the student test between $\mathrm{pH}$ at flowering and after harvest compared to each other for both study sites $(\mathrm{p}=0.00)$. The $\mathrm{pH}$ of the control treatment 
Ben Tshibuyi Kasu-Bandi et al. / American Journal of Agricultural and Biological Sciences 2019, Volume 14: 95.102 DOI: 10.3844/ajabssp.2019.95.102

increased slightly by 0.57 and 0.59 at the Kanyameshi

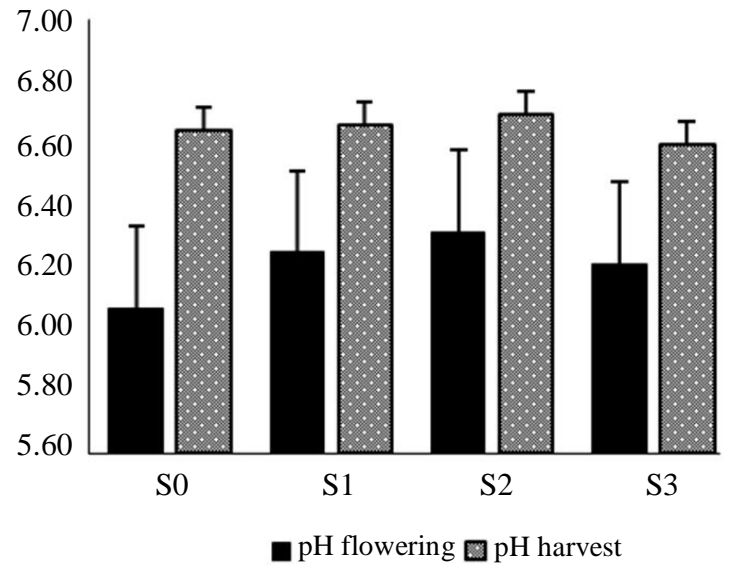

and Kasapa sites respectively at harvest.

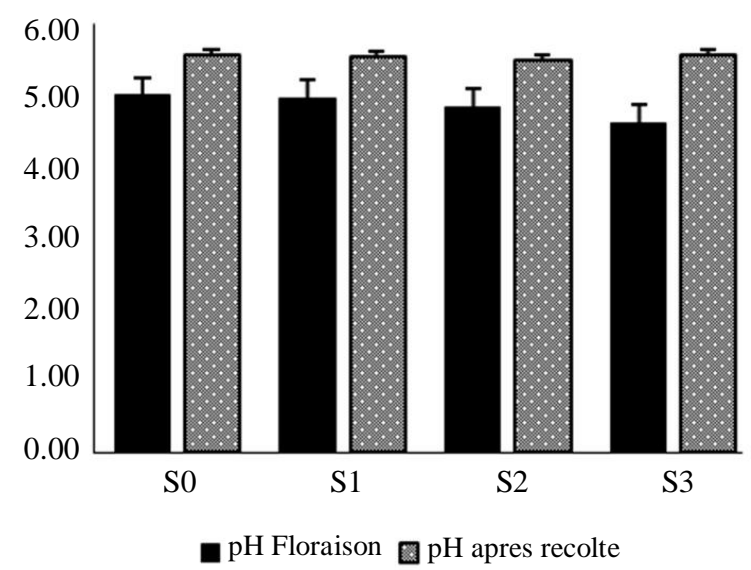

Fig. 1: Effect of rhizobial strains on soil pH change at flowering and harvest. Left for the Kanyameshi site and to the right of Kasapa
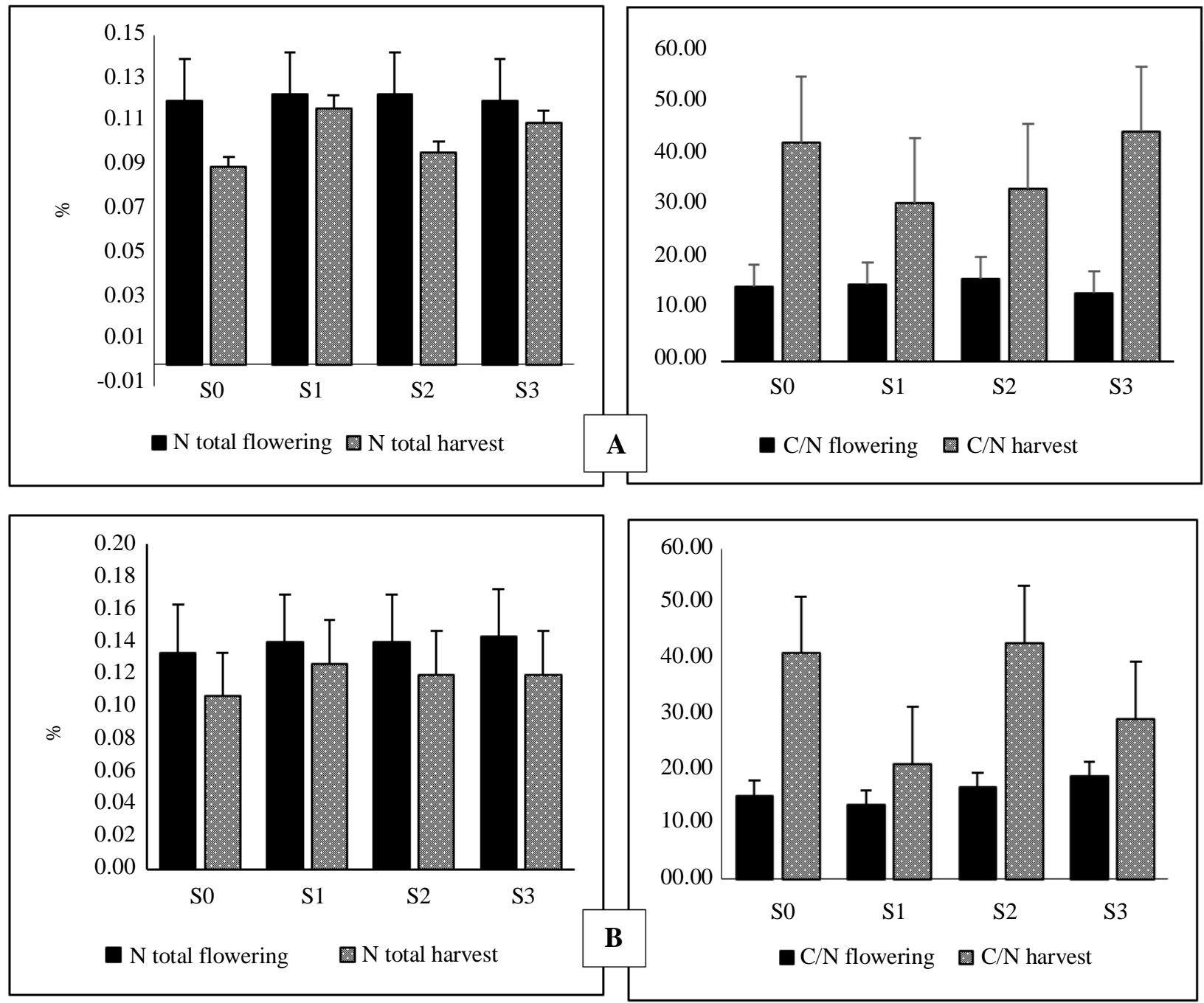

Fig. 2: Influence of Bradyrhizobium inoculation on total nitrogen (left) and soil $\mathrm{C} / \mathrm{N}$ ratio (right) at flowering and harvest. (A): Kanyameshi site and (B): Kasapa site 


\section{Influence of Bradyrhizobium Strains on Soil Chemical Parameters}

Figure 2 indicates that in Kanyameshi the total nitrogen and soil $\mathrm{C} / \mathrm{N}$ ratio are not influenced by the different rhizobium strains at flowering and harvest. The same trend is observed in Kasapa site. Nevertheless, the Student test shows a significant difference in total nitrogen and $\mathrm{C} / \mathrm{N}$ in Kanyameshi after comparing the situation in the soil at flowering and harvest. In Kasapa site, only the $\mathrm{C} / \mathrm{N}$ ratio shows a highly significant difference $(\mathrm{p}=0.00)$. The results show in both sites that soil nitrogen decreases after harvest compared to the flowering. An opposite trend is observed on the $\mathrm{C} / \mathrm{N}$ ratio where in both sites the plots without strains (S0) presented after harvest near the triple of the situation at flowering.
The different rhizobium strain shows a significant effect on total and available phosphorus after soybean harvest in Kanyameshi soil (Fig. 3). Strain S1 had the highest mean total $\mathrm{P}$ and available $\mathrm{P}$ was 756.7 and $129.5 \mu \mathrm{g} . \mathrm{g}^{-1}$ soil, respectively. Whereas, strain S2 recorded the lowest value of the total $\mathrm{P}$ and $\mathrm{S} 3$ for the available $\mathrm{P}$. With regard to the flowering situation in the same site, the ANOVA result reveals similar effects between the strains.

For the Kasapa site, total and available soil phosphorus is not influenced by rhizobial strains applied regardless of the time of observation (i.e., flowering and harvest). Nevertheless, the Student test comparing the moment of observation between them shows a significant difference between the available phosphorus at flowering and harvest and not significant for the total P. The same trend is observed in the Kanyameshi site.
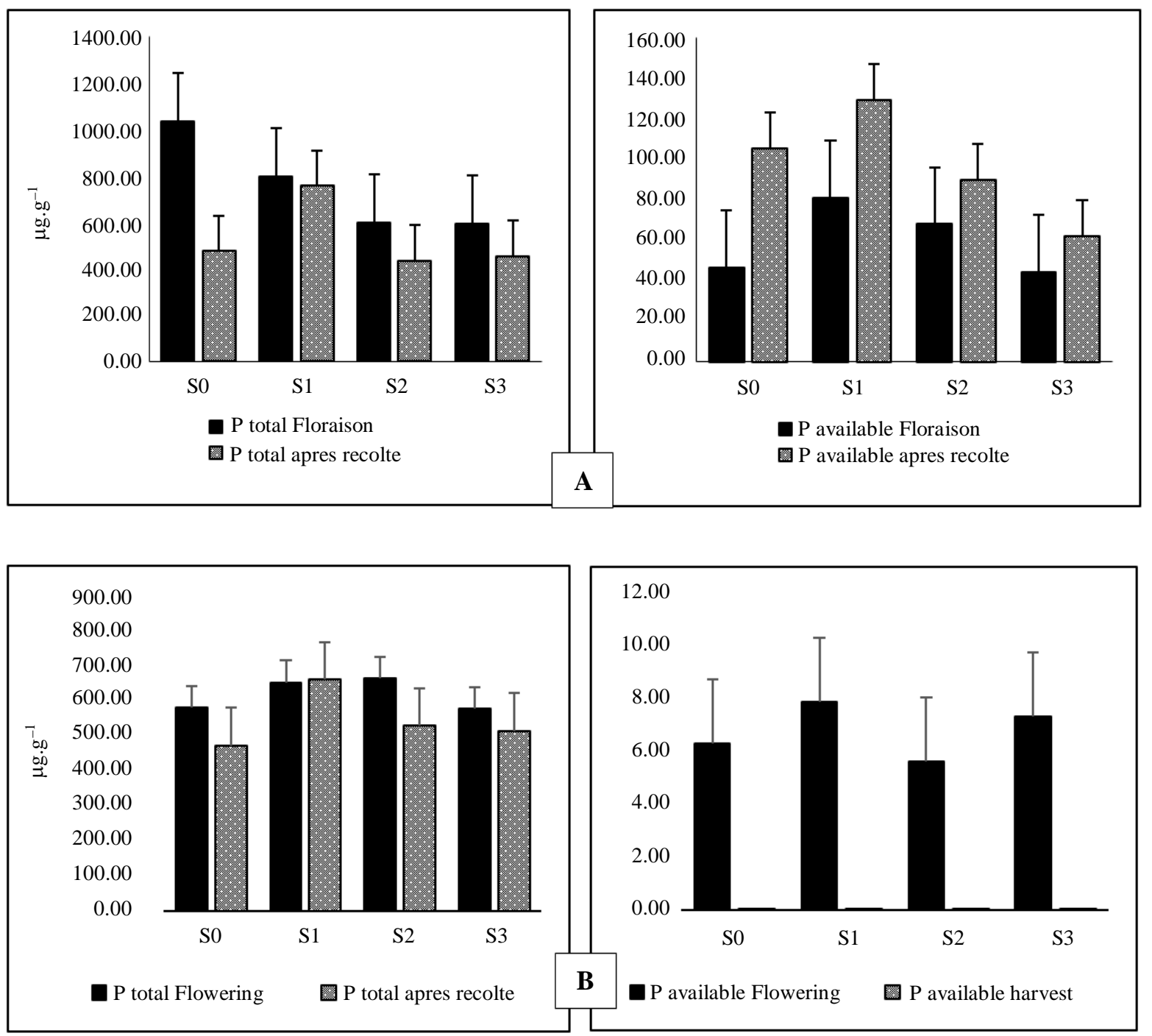

Fig. 3: Influence of Bradyrhizobium inoculation on total phosphorus (left) and available soil phosphorus (right). A: Kanyameshi site and B: Kasapa site 

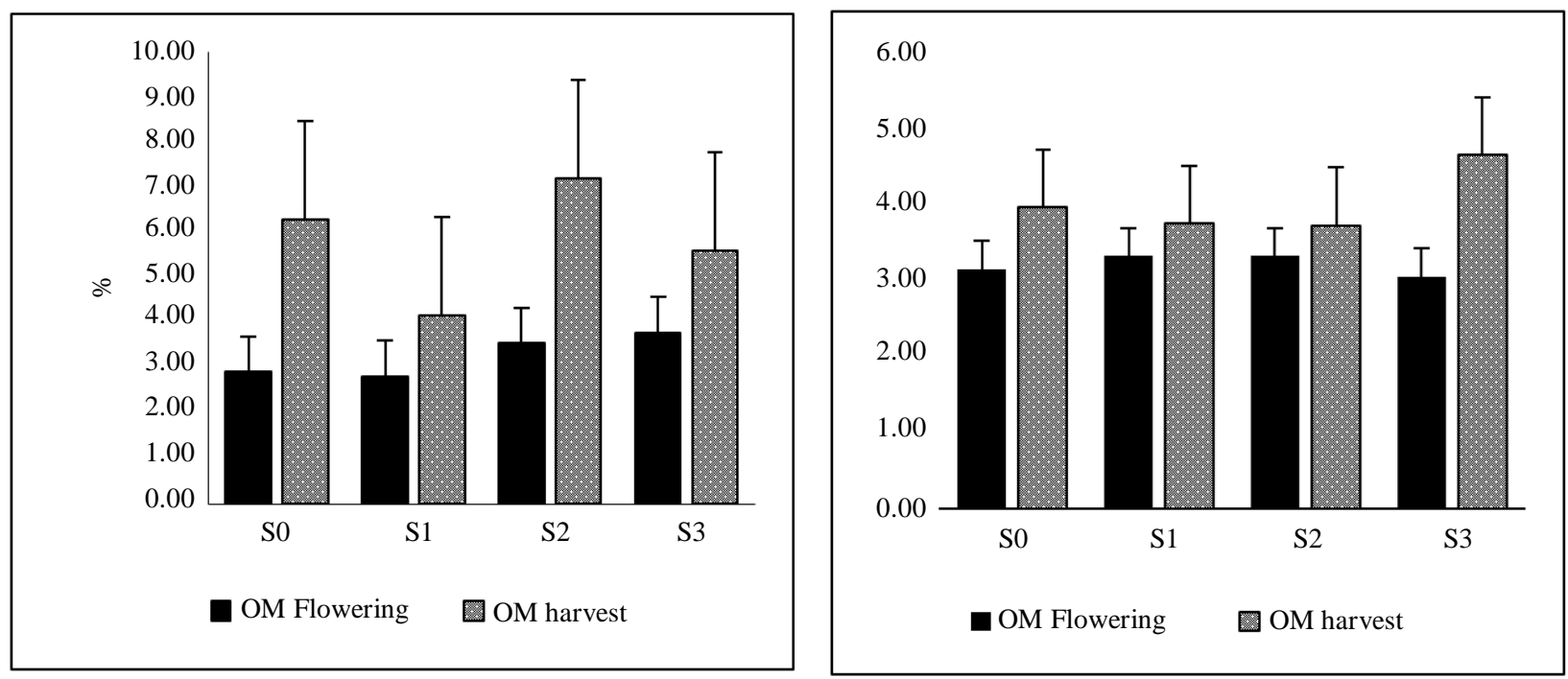

Fig. 4: Influence of inoculation by Bradyrhizobium on organic matter. On the left the site Kanyameshi and on the right the site Kasapa

Figure 4 shows that Bradyrhizobium strains did not produce a significant effect on soil organic matter in both Kanyameshi and Kasapa study sites at flowering and harvest. By comparing the time of observation (i.e., flowering and harvest) between them, the results reveal a highly significant difference for both study sites. These results show that the level of organic matter in the soil has improved after harvest. Thus, the control plots (S0) in the Kanyameshi site show that soil organic matter doubled at harvest.

\section{Discussion}

The results revealed similar effects between different rhizobial strains on $\mathrm{pH}$, Nitrogen, $\mathrm{C} / \mathrm{N}$ ratio and soil organic matter at flowering and harvest in both study sites $(\mathrm{p}>0.05)$. Several studies have shown that the success of inoculation depends not only on the strain itself, but also on its ability to withstand poor environmental conditions (Smil, 2002; Thies et al., 1991; Nazih et al., 1993; Tshibuyi et al., 2019) on the one hand and, on the other hand, to survive in the soil as saprophytic microorganisms beyond the first month following the inoculation (Gibson and Harper, 1985). The $\mathrm{pH}$ under the inoculated treatments remains close to neutral compared to the control inoculated in Kanyameshi site at harvest. Total and available phosphorus, only in the Kanyameshi site was influenced by the different strains of Bradyrhizobium at harvest. Strain S1 had the highest average in total and available $\mathrm{P}$ whereas; strain $\mathrm{S} 2$ recorded the lowest value of the total $\mathrm{P}$ and $\mathrm{S} 3$ for the available $\mathrm{P}$. The diversity of rhizobia, like that of all other microorganisms, is extremely high (Amarger et al.,
1996), which would influence their effectiveness. On the other hand, in the Kasapa site, the different strains did not induce significant effects. Phosphorus deficiency has already been shown to affect the multiplication of rhizobia in the rhizosphere, resulting in reduced infection, reduced nodule growth and inhibited plant activity (Adebayo, 1992). Similarly, phosphorus has already been shown to be one of the many factors affecting yields and symbiotic nitrogen fixation in legumes (Mafongoya et al., 2004). Pereira and Bliss (1989) showed that the amount of nitrogen fixed by the bean is severely limited by phosphorus soil deficiency. This situation could explain the results obtained in this study.

Several authors have reported that the tolerance to environmental stress of Rhizobium strain is a very important factor for good efficiency (Danso et al., 1988). Thus, high temperatures $\left(>40^{\circ} \mathrm{C}\right)$ inhibit nodulation and reduce $\mathrm{N}_{2}$ fixation activity (Kichou and Sahraoui, 2001). The response to temperature likely vary considerably depending on the strains involved. When soil temperatures are high at the surface, nodulation tends to be localized in deeper horizons (Dommergues et al., 1999). Similarly, under conditions of water deficit, the growth and survival of rhizobia are affected (Hungria and Vargas, 2000), nodulation is reduced and $\mathrm{N}_{2}$ fixation is decreased (Brockwell et al., 1995).

By comparing $\mathrm{pH}$ at flowering and harvest, the results showed highly significant differences in all sites. For this result, the $\mathrm{pH}$ increased from flowering to harvest at all sites. For total nitrogen and $\mathrm{C} / \mathrm{N}$, the Student test shows a significant difference on total nitrogen and $\mathrm{C} / \mathrm{N}$ at Kanyameshi whereas in Kasapa only $\mathrm{C} / \mathrm{N}$ showed a significant difference after comparing the situation in the soil at flowering and harvest. However, nitrogen content 
in the soil decreased at harvest and in the case of $\mathrm{C} / \mathrm{N}$, the opposite situation is observed. Nutritional constraints likely limited the symbiotic nitrogen fixation by affecting rhizobial survival and multiplication, initiation, development and nodule functioning and growth of the host plant (Delgado et al., 1994). In both Kanyameshi and Kasapa, the untreated control (SO) showed a postharvest $\mathrm{C} / \mathrm{N}$ ratio that was almost triple the flowering situation. This situation may be the beneficial effect of legumes in improving the soil chemical status through Nitrogen input and resultant decomposition of residues (Diop et al., 2013; N'gbesso et al., 2013).

\section{Conclusion}

The results showed that the different strains of rhizobium did not influence $\mathrm{pH}$, nitrogen, carbonnitrogen ratio and soil organic matter neither at flowering nor at harvest in both Kanyameshi and Kasapa. However, total and available $\mathrm{P}$ were influenced by different strains of rhizobium in Kanyameshi at harvest. The strain S1 managed to induce the highest total $\mathrm{P}$ value and, strain $\mathrm{S} 2$ induced the highest available P. Significant differences were obtained after comparing the situation of soil at flowering and harvesting on $\mathrm{pH}$, total nitrogen, the carbon-nitrogen ratio, organic matter and available $\mathrm{P}$ soil. However, untreated controls (S0) showed after harvest nearly the triple of the situation observed at flowering for $\mathrm{C} / \mathrm{N}$ ratio in Kanyameshi and Kasapa. This increased $\mathrm{C} / \mathrm{N}$ ratio compared to inoculated treatment would suggest that there exists in the rhizosphere a competition between applied and native strains leading to limited $\mathrm{N}_{2}$ uptake and soil fertility improvement.

This study showed that the direct effect of Bradyrhizobium on soil chemical properties is limited at certain strains and environmental conditions.

\section{Acknowledgment}

The authors acknowledge the technical and/ or financial support from CIAT, HarvestPlus, the University of Lubumbashi as well as technicians from INERA or development partners and farmers who participated and/or funded the implementation of this research.

\section{Author's Contributions}

Ben Tshibuyi Kasu-Bandi and Laurent Kidinda Kidinda: Contributed in paper preparation, development and publication.

Germain Nyembo Kasendue, Kasongo Lenge Emery, Antoine Kanyenga Lubobo, John Banza Mukalay, Mick Assani Bin Lukangila, Meschac Ilunga Tshibingu: Contributed in paper preparation and development.
Louis Baboy Longanza: Contributed in paper development.

\section{Ethics}

Authors declare that there not any conflict of interest or any other ethical issues that may arise after the publication of this manuscript. The data are original and from experiments conducted by the Authors of this manuscript.

\section{References}

Adebayo, A., 1992. Nitrogen fixation and management pratices for its enhancement in tropical agriculture. Proceedings of the 5th Conference of AABNF, (BNF' 92), Rabat, Morocco, pp: 14-19.

Amarger, N., G. Laguerre, P. Mavingui, M. Allard and M. Charnay et al., 1996. Typing of Rhizobia by PCR DNA fingerprinting and PCR-restriction fragment length polymorphism analysis of chromosomal and symbiotic gene regions: Application to rhizobium leguminosarum and its different biovars. Applied Environ. Microbiol., 62: 2029-2036.

Baboy, L.L., K.L. Kidinda, K.M. Kilumba, S. Langunu and K.M. Mazinga et al., 2015. Influence of late sowing on growth and yield of Soybean (Glycine max Merril) grown under different spaces in Lubumbashi, DR Congo. Int. J. Innovat. Applied Stud., 12: 104-109.

Brockwell, J., P.J. Bottomley and J.E. Thies, 1995. Manipulation of rhizobia microflora for improving legume productivity and soil fertility: A critical assessment. Plant Soil, 174: 143-180.

Carsky, R.J., R. Abiadoo, K.E. Dashiell and N. Sanginga, 1997. Effect of soybean on subsequent maize grain yield in Guinea savannah of West Africa. Afr. CropSci. J., 5: 31-39.

DOI: $10.4314 /$ acsj.v5i1.27868

Danso, S.K.A., C. Labandera, D. Pastorini and C. Curbalo, 1988. Nitrogen fixation in a two-year old white clover-fescue pasture: Influence of nitrogen fertilization. Soil Biol. Biochem., 20: 261-262. DOI: 10.1016/0038-0717(88)90049-1

Delgado, M.J., F. Ligero and C. Lluch, 1994. Effects of salt stress on growth and nitrogen fixation by pea, faba-bean, common bean and soybean plants. Soil Biol. Biochem., 26: 371-376.

Diop, I., A. Kane, T. Krasova-Wade, K.B. Sanon and P. Houngnandan et al., 2013. Impacts des conditions pédoclimatiques et du mode cultural sur la réponse du niébé (Vignaunguiculata L. Walp.) à l'inoculation endomycorhizienne avec Rhizophagusirregularis. J. Applied Biosci., 69: 5465-5474. DOI: 10.4314/jab.v69i0.95072 
Dommergues, Y., E. Duhoux and H.G. Diem, 1999. Les arbres fixateurs de l'azote: Caractéristiques fondamentales et role dans l'aménagement des écosystèmes méditerranéens et tropicaux avec référence particulier aux zones subhumides et arides. Ed. CIRAD, Editions Espaces, FAO, IR. Montpellier, France.

FAO, 2003. Les Engrais et Leurs Applications: Précis à l'usage des Agents de Vulgarisation Agricole. 1st Edn., Quatrième Édition, FAO, Rabat, pp: 84.

FAO, 2005. Evaluation du Bilan en Éléments Nutritifs du sol. Bulletin Fao Engrais et Nutrition végétale, $\mathrm{n}^{\circ}$ 14. 1st Edn., FAO, Italie, pp: 100.

Gibson, A.H. and J.E. Harper, 1985. Nitrate effect on nodulation of soybean by Bradyrhizobium japonicum. Crop Sci., 25: 497-501.

Houngnandan, P., N. Sanginga, P. Woomer, B. Vanlauwe and O. Van Cleemput, 2001. Response of mucunapruriens to symbiotic nitrogen fixation by rhizobia following inoculation in farmers' fields in the derived savana of Benin. BiolFertil Soil, 33: 416-422.

Hungria, M. and M.A.T. Vargas, 2000. Environmental factors affecting $\mathrm{N}_{2}$ fixation in grain legumes in the tropics, with an emphasis on Brazil. Field Crops Res., 65: 151-164.

Javaheri, F. and J.P. Baudoin, 2001. Le Soja. In: Agriculture en Afrique Tropical (Directorate General for International Cooperation), Raemaerkers R.H. (Ed.), Ministry of Foreign Affairs, External Trade and International Cooperation, Brussels, Belgium, pp: 860-882.

Kasongo, L.M.E. and M.J. Banza, 2015. Evaluation de la réponse du soja aux doses croissantes d'un compost à base de Tithonia diversifolia sur un sol fortement altéré. Int. J. Innovat. Applied Stud., 11: 273-281.

Kasongo, L.M.E., M.T. Mwamba, M.P. Tshipoya and M.J. Mukalay, 2013. Réponse de la culture de soja (Glycine max L. (Merril) à l'apport des biomasses vertes de Tithonia diversifolia (Hemsley) A. Gray comme fumure organique sur un Ferralsol à Lubumbashi, R.D. Congo. J. Applied Biosci., 63: 4727-4735. DOI: 10.4314/jab.v63i1.87247

Kichou, T. and H. Sahraoui, 2001. Effet de la température sur la fixation et L'assimilation de l'azote chez le pois chiche. Céréaliculture. $\mathrm{N}^{\circ} 36$. Ed. A.C.T.E.S Rabat.

Kwey, M.M., S.K. Banze and B.J. BanzeMukalay, 2015. Etude de cas sur l'impact des amendements organiques vis-à-vis de la salinité en culture de bananier. Afrique Sci., 11: 152-160.

Mafongoya, P.L., K.E. Giller, D. Odee, S. Gathumbi and S.K. Ndufa et al., 2004. Benefiting from N2Fixation and Managing Rhizobia. In: Below-ground Interaction in Tropical Agro Ecosystems: Concepts and Models with Multiple Plant Components, Noordwijk, M.V., G. Cadisch and C.K. Ong (Eds.), CARI, pp: 227-241.
Mako, F.P.N., N.C. Kouame and P.Z. Goli, 2013. Evaluation finale du rendement et des paramètres phytosanitaires de lignées de soja [Glycine max (L.) Merrill] dans deux zones agro écologiques de savane de Côte d'Ivoire. Int. J. Biol. Chem. Sci., 7: 574-583. DOI: 10.4314/ijbcs.v7i2.14

Manyong, V.M., K.E. Dashiell, B. Oyewole and G. Blahut, 1996. Spread of new Soybean varieties in atraditional soybeangrowing area of Nigeria. Proceedings of the second Symposium of the African Association of Farming Systems Research Extension and Training, (RET'96), Ouagadougou, Burkina Faso, pp: 151-162.

Mrkovački, N., J. Marinković and R. Aćimović, 2008. Effect of $\mathrm{N}$ fertilizer application on growth and yield of inoculated soybean. Not. Bot. Hort. Agrobot. Cluj, 36: 48-51.

Mulaji, K.C., 2011. Utilisation des composts de biodéchets ménagers pour l'amélioration de la fertilité des sols acides de la province de Kinshasa (République Démocratique du Congo). Thèse de Doctorat, Gembloux Agro Bio Tech.

N'gbesso, M.F.P., L. Fondio, B.E.K. Dibi, H.A. Djidji and C.N. Kouame, 2013. Étude des composantes du rendement de six variétés améliorées de niébé [Vignaunguiculata (L.) Walp]. J. Applied Biosci. 63: 4754-4762. DOI: 10.4314/jab.v63i1.87249

Nazih, N., D. Sen and R.W. Weaver, 1993. Population's densities of Clover rhizobia in Texas pastures and responses to liming. Biol. Fertil. Soils, 15: 45-49. DOI: $10.1007 / \mathrm{BF} 00336287$

Pereira, P.A.A. and F.A. Bliss, 1989. Selection of common bean (Phaseolus vulgaris L.) for N2 fixation at different levels of available phosphorus under field and environmentally controlled conditions. Plant Soil, 115: 75-82.

Shahid, M., S. Khalid, G. Abbas, N. Shahid and M. Nadeem et al., 2009. Heavy Metal Stress and Crop Productivity. In: Crop Production and Global Environmental Issues, Hakeem, K.R. (Ed.), Springer International Publishing, Switzerland, pp: 1-25

Smil, V., 2002. Biofixation and Nitrogen in the Biosphere and in Global Food Production. In: Nitrogen Fixation: Global Perspectives, Brogan, T.M. (Ed.), CAB International, New York, pp: 7-9.

Smith, D.L. and D.J. Hume, 1987. Comparison of assay methods for $\mathrm{N}_{2}$ fixation utilizing white bean and soybean. Can. J. Plant Sci., 67: 11-19.

Tairo, E.V. and P.A. Ndakidemi, 2013. Yields and economic benefits of soybean (Glycine $\max$ L.) as affected by Bradyrhizobium japonicum inoculation and phosphorus supplementation. Am. J. Res. Commun., 1: 159-172. 
Thies, J.E., P.W. Singleton and B.B. Bohlool, 1991. Influence of the size of indigenous rhizobial populations on establishment and symbiotic performance of introduced rhizobia on field-grown legumes. Applied Microbiol. Environ., 57: 19-28. PMID: 16348393

Tshibuyi, K.B.B., K.L. Kidinda, K.G. Nyembo, L.L. Baboy and L.E. Kasongo et al., 2019. Correlations between growth and yield parameters of soybean (Glycine $\max (\mathrm{L}$.$) Merr.) under the influence of$ Bradyrhizobium japonicum in Kipushi (The democratic republic of Congo). Am. J. Agric. Biol. Sci. DOI: 10.3844/ajabssp.2019.86.94

Useni, S.Y., K. Mayele, A.K.P. Kasangij, K.L. Nyembo and L.L. Baboy, 2013. Effets de la date de semis et des écartements sur la croissance et le rendement du niébé (Vignaunguiculata L. Walp) à Lubumbashi, RD Congo. Int. J. Innovat. Applied Stud., 6: 40-47.
Useni, S.Y., M.I. Glady, M.M. Theodore, N.K. Becker and L. Jonas et al., 2014. Amélioration de laqualité des sols acides de Lubumbashi (Katanga, RD Congo) par l'application de différents niveaux de compost de fumiers de poules. J. Applied Biosci., 77: 6523-6533. DOI: 10.4314/jab.v77i1.3.

Van Ranst, E., M. Verloo, A. Demeyer and J.M. Pauwels, 1999. Manual for the Soil Chemistry and Fertility, Laboratory-Analytical Methods for Soils and Plants, Equipment and Management of Consumables. 1st Edn., University of Ghent, Ghent, Belgium, ISBN-10: 9076603014, pp: 243.

Verde, B.S., B.O. Danga and J.N. Mugwe, 2013. Effects of manure, lime and mineral $\mathrm{P}$ fertilizer on soybean yields and soil fertility in a humicnitisol in the Central Highlands of Kenya. Int. J. Agric. Sci. Res., 2: 283-291. 